\title{
Marine Biology \\ Annual and seasonal movements of migrating short-tailed shearwaters reflect environmental variation in sub-Arctic and Arctic waters \\ --Manuscript Draft--
}

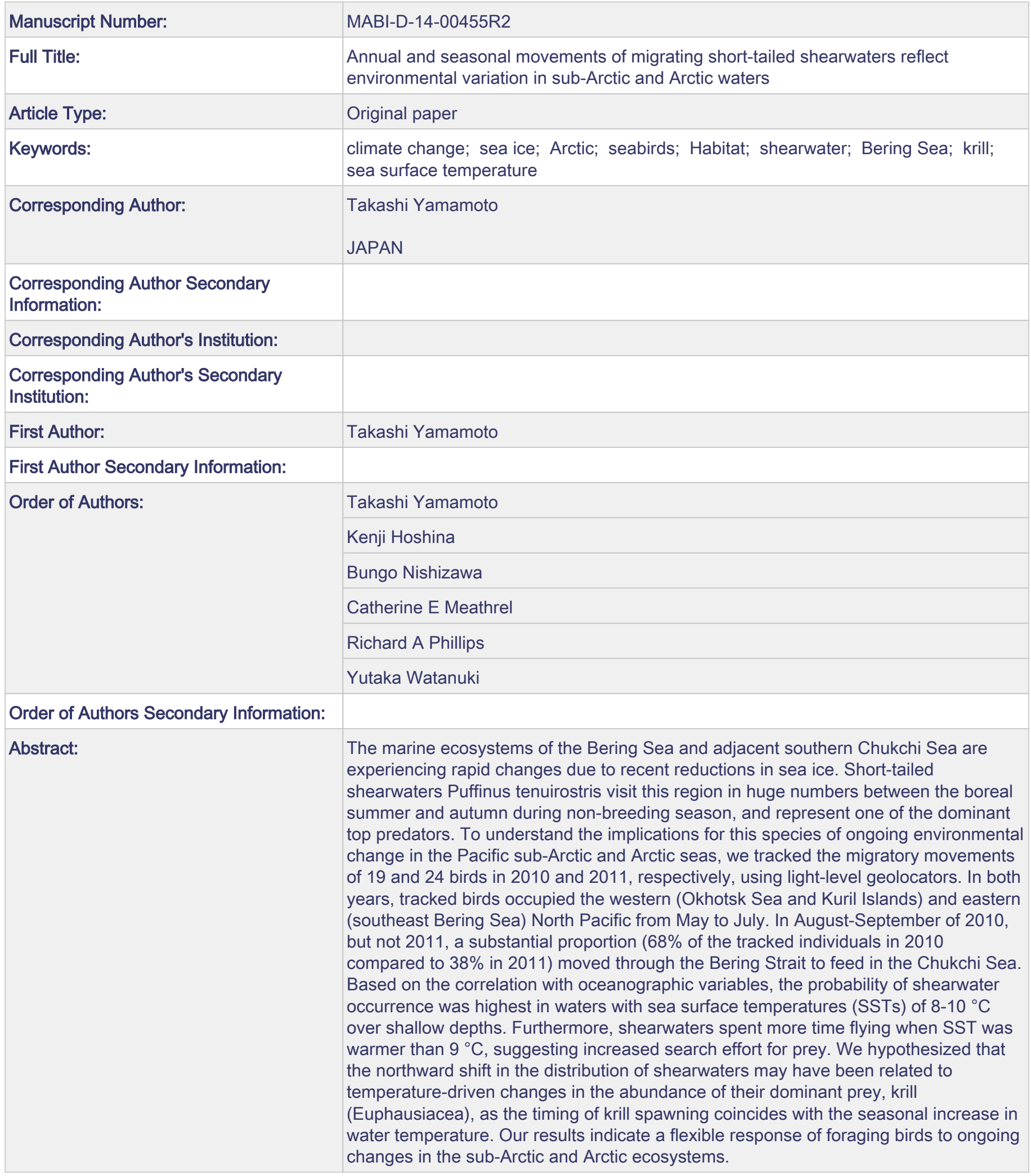


3 Annual and seasonal movements of migrating short-tailed shearwaters reflect

4 environmental variation in sub-Arctic and Arctic waters

5

6 Takashi Yamamoto $^{\mathrm{a}, \mathrm{b}, *}$, Kenji Hoshina $^{\mathrm{b}}$, Bungo Nishizawa ${ }^{\mathrm{b}}$, Catherine E. Meathrel ${ }^{\mathrm{c}}$,

$7 \quad$ Richard A. Phillips ${ }^{d}, Y^{2}$ utaka Watanuki ${ }^{\text {b }}$

8

$9{ }^{a}$ Arctic Environment Research Center, National Institute of Polar Research, 10-3

10 Midori-cho, Tachikawa, Tokyo 190-8518, Japan

$11{ }^{b}$ Graduate School of Fisheries Sciences, Hokkaido University, 3-1-1 Minato-cho,

12 Hakodate, Hokkaido 041-8611, Japan

$13{ }^{\mathrm{C}}$ Department of Environmental Management and Ecology, La Trobe University,

14 Wodonga, VIC 3690, Australia

$15{ }^{d}$ British Antarctic Survey, Natural Environment Research Council, High Cross,

16 Madingley Road, Cambridge CB3 0ET, UK

18 *Email: taka.y@nipr.ac.jp,

19 *Tel\&Fax: (+81) 138-40-8863 
23 Abstract The marine ecosystems of the Bering Sea and adjacent southern Chukchi Sea

24 are experiencing rapid changes due to recent reductions in sea ice. Short-tailed shearwaters Puffinus tenuirostris visit this region in huge numbers between the boreal summer and autumn during non-breeding season, and represent one of the dominant top predators. To understand the implications for this species of ongoing environmental change in the Pacific sub-Arctic and Arctic seas, we tracked the migratory movements of 19 and 24 birds in 2010 and 2011, respectively, using light-level geolocators. In both years, tracked birds occupied the western (Okhotsk Sea and Kuril Islands) and eastern (southeast Bering Sea) North Pacific from May to July. In August-September of 2010, but not 2011, a substantial proportion (68\% of the tracked individuals in 2010 compared to $38 \%$ in 2011) moved through the Bering Strait to feed in the Chukchi Sea. Based on the correlation with oceanographic variables, the probability of shearwater occurrence was highest in waters with sea surface temperatures (SSTs) of $8-10{ }^{\circ} \mathrm{C}$ over shallow depths. Furthermore, shearwaters spent more time flying when SST was warmer than $9{ }^{\circ} \mathrm{C}$, suggesting increased search effort for prey. We hypothesized that the northward shift in the distribution of shearwaters may have been related to temperature-driven changes in the abundance of their dominant prey, krill (Euphausiacea), as the timing of

40 krill spawning coincides with the seasonal increase in water temperature. Our results indicate a flexible response of foraging birds to ongoing changes in the sub-Arctic and Arctic ecosystems. 
46 The Bering and southern Chukchi seas are among the most productive marine ecosystems in the world (Highsmith and Coyle 1990; Grebmeier 2012; Hunt et al. 2013). Reductions in sea ice have been particularly extensive in parts of this region (Shimada et al. 2006; Serreze et al. 2007; Steele et al. 2008; Grebmeier 2012; Post et al. 2013), with changes in water temperature and ice cover affecting the seasonality and biomass of primary production, and hence the distribution and abundance of consumers (Hunt et al. 2002a; Grebmeier et al. 2006; Mueter and Litzow 2008; Hunt et al. 2011; Wassmann 2011; Wassmann et al. 2011; Grebmeier 2012). Among the latter, the top predators (homeothermic marine mammals and seabirds) are mobile and can potentially respond to a varying environment (e.g. a shift in distribution of prey) by switching foraging areas or diet; hence, different aspects of their behaviour can serve as useful indicators of fluctuations in the wider ecosystem (Iverson et al. 2007; Piatt et al. 2007). The short-tailed shearwater Puffinus tenuirostris is a trans-equatorial migrant which breeds in southern Australia from October to March, and spends the non-breeding period from May to September in the northern North Pacific (Serventy 1967; Carey et al. 2014). Up to 16 million birds are thought to migrate to the southern Bering Sea annually, and they represent one of the most abundant seabird species in the Pacific sub-Arctic and Arctic seas in summer and autumn (Schneider and Shuntov 1993; Gall et al. 2013). During this time, they feed mainly on krill (Euphausiacea) (Ogi et al. 1980; Hunt et al. 2002b; Baduini et al. 2006; Toge et al. 2011), principally 
longipes, which are found in waters $<100 \mathrm{~m}$ deep over the continental shelf, at 100-200m, or >200 m, respectively; in addition, T. raschii and T. inermis are mainly found at high latitudes, including the Chukchi Sea, and T. Iongipes in waters off Japan, Okhotsk Sea, and Bering Sea (Nemoto 1962; Lindley 1980; Vidal and Smith 1986; Smith 1991).

As krill are important prey for many species in the northern North Pacific besides seabirds (e.g. walleye pollock Theragra chalcogramma), they play a key role in the food web, as major links in the energy transfer pathway from primary production to higher trophic levels (Aydin and Mueter 2007). Knowledge of the relationship between shearwater distribution and water mass may provide insights into the dynamics of krill abundance and distribution in this region. Previously, ship-based surveys showed that short-tailed shearwaters spend the non-breeding period foraging in waters north of Japan, the Okhotsk Sea, around the Kurile Islands, the northern North Pacific and southeastern Bering Sea; in addition, in August-September, birds are recorded in high densities in the Bering Strait and to as far north as Barrow, at the boundary between the Chukchi and the Beaufort Seas (e.g. Ogi et al. 1980; Piatt et al. 1991; Hunt et al. 1996; Piatt and Springer 2003; Kurasawa et al. 2011; Sigler et al. 2011; Gall et al. 2013). However, as ship surveys are patchy in terms of spatial and temporal coverage, there is little detail on the seasonality of shearwater movements or on the environmental drivers. An alternative approach for studying timing of migration, routes taken, and locations of stop-over and wintering areas etc. involves the tracking of individuals using light-based geolocation, which has been applied in recent years to numerous terrestrial 
and marine taxa (e.g. Phillips et al. 2005; Shaffer et al. 2006; Stutchbury et al. 2009;

90 Egevang et al. 2010). These studies can help elucidate habitat use during the non-breeding period, as well as identify key areas at sea that are species-specific, or represent ecologically or biologically important regions for multiple species or trophic levels (BirdLife International 2004; Le Corre et al. 2012). However, few previous studies have examined changes in non-breeding distribution in relation to seasonal and annual variation in the environment (Pinet et al. 2011; Jessopp et al. 2013). As migrating seabirds are mobile and not subject to central-place reproductive constraints during the non-breeding period, their distributions may better reflect the dynamic aspect of ecosystems than those of breeding birds, providing insights into changes in habitat suitability and possible responses at the population level to ongoing environmental change. Although Carey et al. (2014) used geolocators to provide the first data on the migratory behaviour of individual short-tailed shearwaters in 2008, birds were tracked for a single year and hence their movement patterns in response to annual changes in the marine environment were not measured, and as such, remain unknown.

In this study, we tracked individual movements of short-tailed shearwaters during the non-breeding period (from boreal summer to autumn) in the north Pacific for two years using geolocators. Seasonal and annual differences in their distribution and habitat use were analysed in the context of changes in the dynamic marine environment in the Pacific sub-Arctic and Arctic seas. 
112 Fieldwork was carried out on Great Dog Island (40 $15^{\prime} \mathrm{S}, 148^{\circ} 15^{\prime} \mathrm{E}$; Tasmania,

113 Australia). We captured 50 and 46 incubating short-tailed shearwaters (all different

114 individuals) in early December 2009 and 2010, respectively, and fitted Mk15

115 geolocation-immersion loggers (British Antarctic Survey, Cambridge, UK; hereafter

116 loggers or geolocators), weighing $2.4 \mathrm{~g}$, to the tarsus of each bird using an aluminium

117 band modified according to Carey et al. (2009). The total mass of the geolocator with

118 the leg band was $6.1 \mathrm{~g}$, which represented about $1 \%$ of the mean body mass of the birds

119 (X \pm SD: $591 \pm 52 \mathrm{~g}, n=96)$. All birds were handled for less than 10 min, and then

120 returned to their burrows. We recaptured 16 and 24 equipped birds from their nest burrows or nearby (burrows within $5 \mathrm{~m}$ of the original nest were searched) in early December 2010 and 2011, respectively. One geolocator was recovered from a bird equipped in 2009 that was found dead (cause unknown) on the coast of Australia. In addition, three birds equipped in 2009 were recaptured in 2011, providing data for two years. Data from three loggers recovered in 2011 were corrupted; consequently, usable data were available from the non-breeding period (May-September) for 19 birds in 2010, and 24 birds in 2011, including 3 birds tracked for two seasons.

Data analysis

130 The geolocator measures light levels at $60 \mathrm{~s}$ intervals, and records the maximum value

131 during each $10 \mathrm{~min}$ period. Immersion in seawater was tested every $3 \mathrm{~s}$, and data integrated within each $10 \mathrm{~min}$ period, thereby providing a value from 0 to 200 that 

min after continuous immersion for $20 \mathrm{~min}$. Light data were processed following the procedure in Yamamoto et al. (2010). Sunset and sunrise times were estimated from the thresholds in the light curves. Then, day length was used to estimate latitude and the

137 relative timings of local noon and midnight were used to estimate longitude, providing two positions per day. Simultaneous deployment of geolocators with satellite-transmitters in polar regions has shown a mean location error of $186 \mathrm{~km}$ (Phillips et al. 2004). Locations were not available from light data around the equinoxes because of the inability to estimate latitude from day length at these times of year (Hill 1994). During this period, latitude was therefore estimated by matching water temperature records from the loggers with remotely-sensed sea surface temperature

144 (SST) data (8-day composite, $9 \mathrm{~km}$ resolution, measured by Aqua-MODIS, downloaded from the Ocean Color Web, http://oceancolor.gsfc.nasa.gov at the median daily

146 longitude. Daily positions were filtered according to a threshold speed of $50 \mathrm{~km} \mathrm{~h}^{-1}$ 147 (Spear and Ainley 1997), and missing locations were replaced using linear interpolation. Due to the relative inaccuracy of geolocation (Phillips et al. 2004), we established utilization distributions of the tracked shearwaters for each month

150 (May-September 2010 and 2011) by generating kernel density maps using the ESRI ${ }^{\circledR}$ ArcGIS Spatial Analyst tool, with a cell size of $50 \mathrm{~km}$ and a search radius of $200 \mathrm{~km}$

152 (Phillips et al. 2005). Although tracking data consist of presence locations only, this

153 provides the utilization distribution as a probability gradient. Annual changes in 154 foraging areas were compared by calculating the overlap of the core area (50\% kernel 
polygon) used in the same month between the two study years. To standardize the comparison, we calculated the relative density within a given month as a value from 0

157 (minimum) to 1 (maximum), so that data from different months could be pooled for habitat modeling (see below). Six environmental variables were included in models as potentially correlates or drivers of shearwater distribution: bathymetry (ETOPO1), monthly composite sea surface temperatures (SST: Pathfinder AVHRR), monthly composite chlorophyll $a$ concentration (CHL: Aqua MODIS), monthly composite sea surface height anomalies (SSHA: AVISO), bathymetric gradient (shelf slope), and SST gradient (an index of frontal activity; hereafter "front"). Oceanographic data were obtained from satellite imagery via http://coastwatch.pfel.noaa.gov/coastwatch/CWBrowserWW360.jsp. Given the inherent error in geolocation, the mean value for each environmental covariate within $50 \mathrm{~km}$ grid cells was calculated to obtain a broadly similar spatial resolution to the geolocator positions. The mean and standard deviation of water depth and SST within each $50 \mathrm{~km}$ cell were used to calculate the coefficient of variation, used as the

170 value for shelf slope and front, respectively. Analyses excluded all records with a missing value for any of the remotely-sensed environmental variables, which was usually the consequence of cloud cover during the relevant period. Collinearity was examined by calculating the correlation coefficient of paired explanatory variables using a Spearman's rank correlation matrix; as all correlation coefficients were $<0.64$, all variables were included as candidates in models. 

investigated using generalized additive models (GAMs) (Guisan et al. 2002). Values for the kernel density (ranging from 0 to 1 ) and oceanographic variables at each cell within the potential non-breeding habitat in the North Pacific $\left(30^{\circ} \mathrm{N}-75^{\circ} \mathrm{N}\right.$ by $130^{\circ} \mathrm{E}-125^{\circ} \mathrm{W}$;

Fig. 1) on the same month were determined. The data for each month (May-September 2010 and 2011) were pooled into a single dataset (kernel density as the response, and the environmental variables as predictors), and a smoothed spline fit with all predictors was applied in GAMs, assuming a binomial distribution with the logit-link function. This analysis compared the characteristics of habitat where birds were present, relative to the possible locations during that time period. Models were ranked based on Akaike's Information Criterion (AIC). To test the importance of parameters, the change in $X^{2}$-value between models (Žydelis et al. 2011) was measured with the full dataset (including data from both 2010 and 2011) and reduced datasets (data from either 2010 or 2011) (Table 1). data. As these data can be used to determine whether a bird was flying, or on or under the water, we summed the number of consecutive complete dry events (i.e. records of 0 ), representing the total length of each flight bout. GAMs with a Poisson error distribution were then used to predict changes in the time spent in continuous flight, as an index of the search effort (i.e. distances between prey patches), in relation to mean water temperature recorded by the logger on the same day, considering the flight time as a response variable and the temperature as an explanatory variable. This analysis, which 
examines the activity of shearwaters in relation to water temperature, provides a potential indication of the responses to changes in krill availability. Statistical analyses were carried out in R software (version 2.15.3, R Development Core Team 2008). Habitat modeling and model evaluation were conducted using the R packages mgcv (Wood 2006) and MuMIn (Bartoń 2013).

\section{Results}

At-sea distribution: seasonal and annual differences

Most short-tailed shearwaters departed the breeding latitude $\left(40^{\circ} \mathrm{S}\right)$ in April, spent the main non-breeding period (May-September) in the northern North Pacific (north of $40^{\circ} \mathrm{N}$ ), and began their return migration to colonies from late September to early October (Fig. 1). During the non-breeding period, the tracked short-tailed shearwaters used waters from the northwestern Pacific to southern Okhotsk Sea, and from the Aleutian Islands to southern Chukchi Sea (Fig. 2). The core area of their distribution (within the 50\% kernel density contour) was in the southern Okhotsk Sea and around the Kuril Islands from May to August, and also the eastern Bering Sea from June to August (Fig. 2). In September, their distribution was concentrated over the southwest Chukchi Sea in 2010 (Fig. 2e), but in the same month in 2011 was further south around the northern Bering Sea and Bering Strait, extending over a wider region from the North Pacific to northern Chukchi Sea, and from the Okhotsk Sea to off Barrow (Fig. 2j). Relatively high densities were also apparent around the Aleutian Islands in September (Fig. 2e, j). Comparing the two years, core areas overlapped to a higher degree from 
May to July (42-95\%), than in August and September (9-31\%). At the individual level,

221

222

223

224

225

226

227

228

229

230

231

232

233

234

235

236

237

238

239

240

241

shearwaters showed two different movement patterns; using waters either towards the east coast of Japan, or in the south-central Bering Sea around the Aleutian Islands (ESM 1). Some birds that migrated initially to waters off Japan or the eastern Bering Sea later moved to the Aleutian Islands or into the Chukchi Sea, whereas birds never moved to waters off Japan after spending time in the Bering Sea or Aleutian Islands. In August-September, 13 of 19 birds (68\%) moved into the Chukchi Sea in 2010, but only nine of 24 birds (38\%) in 2011. Individuals tracked for two years showed broadly the same migratory patterns in terms of space and time between the years (ESM 2).

However, the core area of their distribution in August-September appeared to differ between two years, as their distributions were more concentrated in northern areas in 2010 than in 2011.

\section{Environmental characteristics}

Overall, short-tailed shearwaters appeared to utilize a wide range of habitats throughout the non-breeding period in the North Pacific (Fig. 3). The tracked birds were distributed over areas with SSTs of $0-25^{\circ} \mathrm{C}$ in both years, and showed a seasonal pattern in habitat use, tending to be associated with increasingly warm waters until August, and then with cooler waters in September. In the North Pacific, they were distributed primarily over shallow depths ( $>200 \mathrm{~m})$, but also occupied relatively deep waters of $<5,000 \mathrm{~m}$ in May and August (Fig. 3), probably during the post-breeding migration to the North Pacific, and while in the eastern North Pacific (Aleutian Islands, southeastern Bering Sea, and 
242 Chukchi Sea) (Fig. 2, ESM 1). Primary productivity in the areas used by the

243 shearwaters increased from May to July, but then decreased towards September. There

244 were no clear seasonal trends in the other environmental variables, and shearwater

245 densities were not related to SSHA, front, or shelf slope (Fig. 3).

The best-fitting model predicting the oceanographic habitat of short-tailed

247 shearwaters during the non-breeding period included water depth, productivity, SST,

248 front, and SSHA. Based on the comparison of $X^{2}$ values, the probability of shearwater

249 occurrence varied mainly with changes in SST and water depth, and to a lesser extent,

250 primary productivity and front (Table 1, Fig. 4). According to model response curves,

251 the probability of occurrence was highest at SSTs of $8-10{ }^{\circ} \mathrm{C}$ at shallow $(>200 \mathrm{~m})$ and

252 mid-range depths (1,000-2,000 m) (Fig. 4). Although the model also suggested that

253 shearwater occurrence increases again over very deep water $(<6,000 \mathrm{~m})$, this is not

254 reliable given the wide confidence interval. The model response curves did not show

255 clear relationships between shearwater occurrence and the other variables.

256 In the North Pacific, SST -the dynamic environmental variable that was most

257 closely related to the distribution of tracked birds- increased seasonally from summer to

258 autumn. Based on the maps of SST distribution in July-September 2010 and 2011 (Fig.

259 5), the surface temperatures over the shelf region of the Bering Sea ( $>200 \mathrm{~m}$ depth)

260 were relatively cool in 2011 than in 2010. In particular, SSTs along the Alaskan coast,

261 including waters off Barrow, were warmer in September 2010 than in 2011 (Fig. 5c, f),

262 when shearwater distribution was more concentrated in the northern Bering Sea and

263 Chukchi Sea (Fig. 2e, j). The duration of bouts of continuous flight changed in relation 
264 to water temperature, with more time flying in areas of water temperatures warmer than $2659{ }^{\circ} \mathrm{C}$ (Fig. 6).

Discussion

268 The overall patterns of migratory movements by the short-tailed shearwaters in our 269 study was broadly similar to that reported by Carey et al. (2014); birds started the 270 northward migration in the mid-late April, spent May-mid September in areas that 271 ranged from waters off Japan to the northern Bering Sea and the Chukchi Sea, and began their return migration in late September-early October. Although the accuracy of geolocation is relatively low regardless of whether latitudes are light-based or estimated using water temperatures (Phillips et al. 2004, Teo et al. 2004) and our data were limited to a single breeding colony, our analyses nevertheless show convincingly that the shifts in at-sea distribution of the tracked birds were related to seasonal and annual changes in the marine environment of the Pacific sub-Arctic and Arctic seas. Ship-based surveys may provide valuable quantitative data on at-sea distribution of seabirds at finer spatial scales (Gall et al. 2013; Wong et al. 2014), but do not allow individuals to be followed for long periods, or reveal the dynamics of seabird movements beyond the areas surveyed.

At the end of the breeding season, the short-tailed shearwaters tracked from the Great Dog colony in Tasmania migrated north to spend May-July in waters of the western (Okhotsk Sea and around the Kuril Islands) and eastern (southeast Bering Sea) 
that suggested in previous analyses of at-sea survey data (Schneider et al. 1986;

287 Schneider 1997; Schneider and Shuntov 1993; Kurasawa et al. 2011). In the Northern

288

289

290

291

292

293

294

295

296

297

298

299

300

301

302

303

304

305

306

307

Hemisphere, short-tailed shearwaters feed predominantly on krill, particularly $T$. raschii

and T. inermis, and to a lesser extent, T. Iongipes (Ogi et al. 1980; Hunt et al. 2002b;

Baduini et al. 2006). T. raschii is generally found in waters $<100 \mathrm{~m}$ deep over the

continental shelf, T. inermis in mid-water ( 150-200 m deep), and T. Iongipes in pelagic

regions (>200 m bottom depth) (Nemoto 1962; Lindley 1980; Vidal and Smith 1986;

Smith 1991). Krill are usually abundant and widespread in shelf regions, especially in the southeast Bering Sea (Sigler et al. 2012).

From August to September, the tracked shearwaters moved into the southern

Chukchi Sea. This seasonal change in their distribution appeared to coincide with the change in availability of their main prey. Krill forms surface mating swarms usually at depths of 30-45 m (Smith and Adams 1988; Hanamura et al. 1989; Hunt et al. 1996;

Vlietstra et al. 2005), which are accessible to short-tailed shearwaters that can dive up to $70 \mathrm{~m}$ (Weimerskirch and Cherel 1998). Spawning of high-latitude krill species is coupled with the onset of the phytoplankton bloom, usually in April-May in the Okhotsk and Bering seas (Ponomareva 1966; Smith 1991). Although the density of shearwaters was not related to remotely-sensed values for primary productivity, this is probably because of the lag between the timing of plankton blooms and increased prey abundance at higher trophic levels (Stafford et al. 2010). Because the timing of krill spawning progresses across the shelf, coincident with the seasonal increase in water temperature (Smith 1991), krill biomass increases and peaks relatively late in the 
northern Bering Sea (Berline et al. 2008). Krill are likely to cease swarming when SSTs

309 become warm $\left(>7-10{ }^{\circ} \mathrm{C}\right.$ for $T$. inermis $)$, and they descend to deep and cool water

310 (Hanamura et al. 1989; Kotori 1994; Iguchi and Ikeda 2004). Thus, if warm SST

311 reduces the availability of krill for short-tailed shearwaters, this would explain the

312 overall northward shift in their distribution from summer to autumn. This hypothesis

313 was also supported, in part, by the analysis of foraging behaviour, as the tracked

314 shearwaters increased the duration of bouts of continuous flight in areas with water

315 temperatures $>9{ }^{\circ} \mathrm{C}$. Activity patterns of seabirds (e.g. time spent in flight, and landings

316 on the water surface) appear to reflect resource availability (i.e. prey abundance and

317 distances between patched) and hence foraging effort (Weimerskirch et al. 2005; Phalan

318 et al. 2007; Mackley et al. 2010). The changes in activity of short-tailed shearwaters

319 suggested that availability of krill within the birds' diving range decreases with

320 increasing water temperatures, and, consequently, that their search effort probably has

321 to increase because foraging is efficient only where krill occur in high density swarms

322 (Lovvorn et al. 2001).

Although Thysanoessa spp. are endemic to the Bering and Okhotsk seas

324 (Brinton 1962; Ponomareva 1966; Dalpadado and Skjoldal 1991), large zooplankton

325 including krill (mainly $T$. raschii and T. inermis) are transported into the southern

326 Chukchi Sea through the Bering Strait during summer at the confluence of the Alaskan

327 Coastal, Anadyr and Bering Shelf water masses (Springer et al. 1989; Piatt and Springer

328 2003; Grebmeier et al. 2006; Berline et al. 2008). Transport rates are assumed to peak in

329 late July or early August (Hunt et al. 2013). Although direct observations of seasonal 
abundance of krill in the southern Chukchi Sea are limited, several previous studies

331 confirm the presence of krill in autumn (Bluhm et al. 2007; Hopcroft et al. 2010; Eisner et al. 2013), and aggregations or movements of other krill-eating predators (including

333 fish, seabirds, and whales) into the region at this time of year (Moore et al. 1995; Lowry et al. 2004; Bluhm et al. 2007; Moss et al. 2009; Gall et al. 2013; Hunt et al. 2013). The distribution of short-tailed shearwaters in September was concentrated in more northwesterly waters, between the Bering Strait and western Chukchi Sea, in 2010, whereas birds were more widely distributed in the Chukchi Sea, including waters off the Barrow in 2011. Annual variation in the abundance of short-tailed shearwaters in the northeastern Chukchi Sea has also been reported by Gall et al. (2013). In our study, the surface temperatures over the shelf region $(<200 \mathrm{~m}$ depth) which were the core areas used by short-tailed shearwaters in the Bering and Chukchi seas were warmer in 2010 than in 2011, particularly along the Alaskan coast, including waters off the Barrow (Fig. 5c, f). As such, differences in SST might explain the annual variation in shearwater distribution in the Chukchi Sea, as short-tailed shearwaters movements appear to follow the temperature-driven changes in the abundance or availability of krill (see above). The volume of Pacific water transported north through the Bering Strait appears to have a major influence not only on water temperature in the southern Chukchi Sea (Woodgate et al. 2010), but also on the biomass of zooplankton that enters this region (Berline et al. 2008; Matsuno et al. 2012). The mean transport rate was actually higher in 2011, leading to increased warming of mid to deep, but not surface waters (Woodgate et al. 
might reflect increased vertical mixing that resulted in cooler SST in 2011 (Woodgate et

353 al. 2012). Both planktivorous and piscivorous seabirds appear to prefer foraging in

354 well-stratified water where prey are likely to be concentrated (Piatt and Springer 2003).

355 In addition, low seabird abundance in the Chukchi Sea has in the past been associated

356 with cooler water temperatures and weak stratification (Gall et al. 2013). Presumably

357 the tracked short-tailed shearwaters moved north in order to utilize the relatively high

358 food concentrations available after the main bloom in the south had passed. Shearwaters

359 must have sufficient energy reserves prior to the southward migration to complete the

360 long journey (ca. 18 days) (Carey et al. 2014), because, as in the sooty shearwater

361 Puffinus griseus, tracked birds do not appear to stop for intensive refueling en route

362 (Shaffer et al. 2006).

Although the general pattern was of a northerly movement, nevertheless, a proportion of the tracked short-tailed shearwaters also used waters in the Okhotsk Sea and around the Aleutian Islands until September. The shallow channels of the Aleutian Islands are known to generate localized physical features such as eddies and fronts

367 (Coyle 2005; Vlietstra et al. 2005). Frontal regions generally enhance phytoplankton production which supports the food necessary to sustain mating swarms of krill long

369 after near-surface phytoplankton concentrations elsewhere have decreased, and thus may ensure high availability of zooplankton for prolonged periods for planktivorous predators including short-tailed shearwaters (Coyle and Cooney 1993; Schneider and Shuntov 1993; Hunt et al. 1996; Jahncke et al. 2005; Vlietstra et al. 2005). Also, frontal systems appear to entrain krill in shallow water through physical processes that make 
them accessible for shearwaters (Hunt et al. 1996, 1998; Ladd et al. 2005; Vlietstra et al.

375 2005). However, we were not able to detect a clear effect of frontal strength on shearwater distribution, possibly due to the relatively low spatial resolution of geolocation (mean error of ca. 100-150 km: Phillips et al. 2004; Teo et al. 2004) compared with the scale of frontal features (often $<10$ s of kilometers: Ladd et al. 2005; Vlietstra et al. 2005).

Another factor for which we could not account that might explain shearwater distribution relates to their diet diversity and capacity for prey switching. Previous studies reported that, in addition to krill, short-tailed shearwaters also feed on a wide range of alternative prey (sandlance Ammodytes hexapterus, age-0 walleye pollock, copepods, and amphipods Parathemisto libel/ula) (Ogi et al. 1980; Hunt et al. 1996, 2002b; Baduini et al. 2006). In the southeast Bering Sea, the importance of these other prey may increase when the availability of krill is low during a warm year (Baduini et al. 2001; Coyle and Pinchuk 2002; Hunt et al. 2002b). In addition, the main prey species varies among regions, and for example is fish in waters around the Kuril Islands (Ogi et al. 1980). Therefore, the response of the shearwaters to seasonal changes in physical and biological conditions is likely to depend on the region, due to differences in the annual cycle and environmental association of their particular prey. appear to relate to distance from the sea ice edge in the Pacific sub-Arctic and Arctic seas (Fig. 2), though we did not consider the distance to sea ice as an explanatory variable in the habitat analysis because birds arrived in the southeastern Bering Sea long 
after the retreat of sea ice through the Bering Strait, and left the northern Bering Sea and southern Chukchi Sea during the period of minimum sea ice extent in these regions (September: Grebmeier et al. 2006) (Figs. 1,2). Nevertheless, our study indicated that short-tailed shearwaters might follow seasonal availability of krill that is driven to some extent by changes in sea ice timing and extent, which affects water temperatures and primary productivity (Smith 1991; Deibel and Daly 2007). Our results indicate a flexible response of foraging birds to ongoing changes in the sub-Arctic and Arctic ecosystems. This is also implied, in part, from the limited samples of individuals that were tracked for two non-breeding season; they showed a broadly similar spatio-temporal movement patterns in both years, but utilized more northern areas in 2010 (ESM 2) when SSTs were relatively warmer over the shelf (Fig. 5). Hence, the expected future reduction in sea ice will possibly shift the distribution of shearwaters northwards. The movements of this species may therefore provide a useful indicator of wider ecosystem changes, especially in krill availability, in this region, unless other environmental changes associated with reduced sea ice result in a shift in diet of short-tailed shearwaters from krill to other types of prey (Hunt et al. 2002b). Given the huge numbers of shearwaters that migrate to this region, changes in the size or species composition of their diet, as well as in their foraging locations, may have a top-down influence on the abundance or distribution of their prey (Ressler et al. 2012), with potentially major effects on energy transfer pathways in local marine ecosystems, and on food web structure in general (Schneider et al. 1986; Aydin and Mueter 2007). 
419 for the field assistance, and Kohei Matsuno, Mark J. Carey, George Hunt and an anonymous reviewer for useful comments on the manuscript. The study was supported by the Japanese Society for Promotion of Science (\#20241001, \#22405007) and Green

Network of Excellence Program funded by the Ministry of Education, Culture, Sports,

Animal Ethics Proejct AEC 10/32 (W) and Tasmanian Department of Primary by CE Meathrel.

References

Aydin K, Mueter F (2007) The Bering Sea-a dynamic food web perspective. Deep-Sea Res II 54:2501-2525 events. Mar Ecol Prog Ser 222:265-277

Baduini CL, Hunt Jr. GL, Pinchuk AI, Coyle KO (2006) Patterns in diet reveal foraging

Baduini CL, Lovvorn JR, Hunt Jr. GL (2001) Determining the body condition of short-tailed shearwaters: implications for migratory flight ranges and starvation

Bartoń K (2013) MuMIn: Multi-model inference. R package version 1.9.0. 
439

440

441

442

443

444

445

446

447

448

449

450

451

452

453

454

455

456

457

458

459

460

Berline L, Spitz YH, Ashjian CJ, Campbell RG, Maslowski W, Moore SE (2008) Euphausiid transport in the Western Arctic Ocean. Mar Ecol Prog Ser 360:163-178

BirdLife International (2004) Tracking ocean wanderers: the global distribution of albatrosses and petrels. BirdLife International, Cambridge, United Kingdom

Bluhm BA, Coyle KO, Konar B, Highsmith R (2007) High gray whale relative abundances associated with an oceanographic front in the south-central Chukchi Sea. Deep-Sea Res II 54:2919-2933

Brinton E (1962) The distribution of Pacific krill. Bulletin of the Scripps Institution of Oceanography of the University of California 8:51-269

Carey MJ, Meathrel CE, May NA (2009) A new method for the long-term attachment of data-loggers of shearwaters (Procellariidae). Emu 109:310-315

Carey MJ, Phillips RA, Silk JRD, Shaffer SA (2014) Trans-equatorial migration of Short-tailed Shearwaters revealed by geolocators. Emu 114:352-359

Coyle KO (2005) Zooplankton distribution, abundance and biomass relative to water masses in eastern and central Aleutian Island passes. Fish Oceanogr 14:77-92

Coyle KO, Cooney RT (1993) Water column sound scattering and hydrography around the Pribilof Islands, Bering Sea. Cont Shelf Res 13:803-827

Coyle KO, Pinchuk AI (2002) The abundance and distribution of krill and zero-age pollock on the inner shelf of the sourheast Bering Sea near the Inner Front in 1997-1999. Deep-Sea Res 49:6009-6030

Dalpadado P, Skjoldal HR (1991) Distribution and life history of krill from the Barents Sea. Polar Res 10:443-460 
Deibel D, Daly KL (2007) Zooplankton processes in Arctic and Antarctic polynyas. In: Smith WO, Barber D (eds) Polynyas: windows into polar oceans. Elsevier Oceanography Series 74, pp 271-322

Egevang C, Stenhouse IJ, Phillips RA, Petersen A, Fox JW, Silk JRD (2010) Tracking of Arctic Terns Sterna paradisaea reveals longest animal migration. Proc Natl Acad Sci USA 107:2078-2081

Eisner L, Hillgruber N, Martinson E, Maselko J (2013) Pelagic fish and zooplankton species assemblages in relation to water mass characteristics in the northern Bering and southest Chukchi seas. Polar Biol 36:87-113

Gall AE, Day RH, Weingartner TJ (2013) Structure and variability of the marine-bird community in the northeastern Chukchi Sea. Cont Shelf Res 67:96-115

Grebmeier JM (2012) Shifting patterns of life in the Pacific Arctic and sub-Arctic Seas. Annu Rev Mar Sci 4:63-78

Hanamura Y, Kotori M, Hamaoka S (1989) Daytime surface swarms of the euphausiid 482 
483

484

485

486

487

488

489

490

491

492

493

494

495

496

497

498

499

500

501

502

503

504

Highsmith RC, Coyle KO (1990) High productivity of northern Bering Sea benthic amphipods. Nature 344:862-864

Hill RD (1994) Theory of geolocation by light levels. In: Le Boeuf BJ and Laws RM (eds) Elephant Seals: Population Ecology, Behavior and Physiology, University of California Press, pp 227-236

Hopcroft RR, Kosobokova KN, Pinchuk AI (2010) Zooplankton community patterns in the Chukchi Sea during summer 2004. Deep-Sea Res II 57:27-39

Hunt Jr. GL, Coyle KP, Hoffman S, Decker MB, Flint EN (1996) Foraging ecology of short-tailed shearwaters near the Pribilof Islands, Bering Sea. Mar Ecol Prog Ser 141:1-11

Hunt Jr. GL, Russell RW, Coyle KO, Weingartner T (1998) Comparative foraging ecology of planktivorous auklets in relation to ocean physics and prey availability. Mar Ecol Prog Ser 167:241-259

Hunt Jr. GL, Stabeno P, Walters G, Sinclair E, Brodeur RD, Napp JM, Bond NA (2002a) Climate change and control of the southeastern Bering Sea pelagic ecosystem. Deep-Sea Res II 49:5821-5853

Hunt Jr. GL, Baduini C, Jahncke J (2002b) Diets of short-tailed shearwaters in the southeastern Bering Sea. Deep-Sea Res 49:6147-6156

Hunt Jr. GL, Coyle KO, Eisner LB, Farley EV, Heintz RA, Mueter F, Napp JM, Overland JE, Ressler PH, Salo S, Stabeno PJ (2011) Climate impacts on eastern Bering Sea foodwebs: a synthesis of new data and an assessment of the Oscillating Control Hypothesis. ICES J Mar Sci 68:1230-1243 
505

506

507

508

509

510

511

512

513

514

515

516

517

518

519

520

521

522

523

525

524 Shearwater and breeding Rhinoceros Auklet and their prey in the northern Sea of

Hunt Jr. GL, Blanchard AL, Boveng P, Dalpadado P, Drinkwater KF, Eisner L, Hopcroft RR, Kovacs KM, Norcross BL, Renaud P, Reigstad M, Renner M, Skjoldal HR, Whitehouse A, Woodgate RA (2013) The Barents and Chukchi Seas: Comparison of two Arctic shelf ecosystems. J Mar Syst 109-110:43-68

Iguchi N, Ikeda T (2004) Vertical distribution, population structure and life history of Thysanoessa longipes (Crustacea: Euphausiacea) around Yamato Rise, central Japan Sea. J Plankton Res 26:1015-1023

Iverson SJ, Springer AM, Kitaysky AS (2007) Seabirds as indicators of food web structure and ecosystem variability: qualitative and quantitative diet analyses using fatty acids. Mar Ecol Prog Ser 352:235-244

Jahncke J, Coyle KO, Zeeman SI, Kachel NB, Hunt Jr. GL. (2005) Distribution of foraging shearwaters relative to inner front of SE Bering Sea. Mar Ecol Prog Ser $305: 219-233$

Jessopp MJ, Cronin M, Doyle TK, Wilson M, McQuatters-Gollop A, Newton S, Phillips RA (2013) Transatlantic migration by post-breeding puffins: a strategy to exploit a temporarily abundant food resource? Mar Biol 160:2755-2762

Kotori M (1994) Krill fishery and biology: Krill fishery in the west-coast of Hokkaido. Gekkan Kaiyo 26:248-250

Kurasawa K, Honda S, Watanuki Y (2011) Distribution of migrating Short-tailed 25 Japan, Hokkaido in spring. Jpn J Ornithol 60:216-227 
526 Ladd C, Jahncke J, Hunt Jr. GL, Coyle KO, Stabeno PJ (2005) Hydrographic features

527 and seabird foraging in Aleutian Passes. Fish Oceanogr 14:178-195

528 Le Corre M, Jaeger A, Pinet P, Kappes MA, Weimerskirch H, Catry T, Ramos JA,

529 Russell JC, Shah N, Jaquemet S (2012) Tracking seabirds to identify potential

530 Marine Protected Areas in the tropical western Indian Ocean. Biol Conserv

$531 \quad 156: 83-93$

532 Lindley JA (1980) Population dynamics and production of krill II. Thysanoessa inermis

533 and T. raschi in the North Sea and American coastal waters. Mar Biol 59:225-233

534 Lovvorn JR, Baduini CL, Hunt Jr. GL (2001) Modeling underwater visual and filter

535 feeding by planktivorous shearwaters in unusual sea conditions. Ecology

$536 \quad 82: 2342-2356$

537 Lowry LF, Sheffield G, George JC (2004) Bowhead whale feeding in the Alaskan

538 Beaufort Sea, based on stomack contents analyses. J Cetacean Res Manage

$539 \quad 6: 215-223$

540 Mackley EK, Phillips RA, Silk JRD, Wakefield ED, Afanasyev V, Fox JW, Furness RW

541 (2010) Free as a bird? Activity patterns of albatrosses during the nonbreeding period.

$542 \quad$ Mar Ecol Prog Ser 406:291-303

543 Matsuno K, Yamaguchi A, Imai I (2012) Biomass size spectra of mesozooplankton in

544 the Chukchi Sea during the summers of 1991/1992 and 2007/2008: an analysis

545 using optical plankton counter data. ICES J Mar Sci 69:1205-1217

546 Moore SE, George JC, Coyle KO, Weingartner TJ (1995) Bowhead whales along the

$547 \quad$ Chukotka Coast in autumn. Arctic 48:155-160 
Moss JH, Murphy JM, Farley Jr. EV, Eisner LB, Andrews AG (2009) Juvenile Pink and

549 Chum salmon distribution, diet, and growth in the Northern Bering and Chukchi Seas. N Pac Anadr Fish Comm Bull 5:191-196

551

Mueter FJ, Litzow MA (2008) Sea ice retreat alters the biogeography of the Bering Sea continental shelf. Ecol Appl 18:309-320

553

Nemoto T (1962) Distribution of five main krill in the Bering and the Northern part of

555

556

557

558

559

560

561

562

563

564

565

566

567

568 the North Pacific. J Oceanogr Soc Japan, 615-627

Ogi H, Kubodera T, Nakamura K (1980) The pelagic feeding ecology of the Short-tailed Shearwaters Puffinus tenuirostris in the Subarctic Pacific Region. J Yamashina Inst Ornithol 12:157-182

Phalan B, Phillips RA, Silk JRD, Afanasyev V, Fukuda A, Fox J, Catry P, Higuchi H, Croxall JP (2007) Foraging behaviour of four albatross species by night and day. Mar Ecol Prog Ser 340, 271-286

Phillips RA, Silk JRD, Croxall JP, Afanasyev V, Briggs DR (2004) Accuracy of geolocation estimates for flying seabirds. Mar Ecol Prog Ser 266:265-272

Phillips RA, Silk JRD, Croxall JP, Afanasyev V, Bennett VJ (2005) Summer distribution and migration of nonbreeding albatrosses: individual consistencies and implications for conservation. Ecology 86:2386-2396

Piatt JF, Wells JL, MacCharles A, Fadely BS (1991) The distribution of seabirds and fish in relation to ocean currents in the southeastern Chukchi Sea. In: Montevecchi WA, Gaston AJ (eds) Studies of High-Latitude Seabirds: Behavioral, Energetic, and 

$34: 21-31$

571

572

573

574

575

576

577

578

579

580

581

582

583

584

585

586

587

588

589

590

Piatt JF, Springer AM (2003) Advection, pelagic food webs and the biogeography of seabirds in Beringia. Mar Ornithol 31:141-154

Piatt JF, Sydeman WJ, Wiese F (2007) Introduction: a modern role for seabirds as indicators. Mar Ecol Prog Ser 352:199-204

Pinet P, Jaquemet S, Pinaud D, Weimerskirch H, Phillips RA, Le Corre M (2011) Migration, wintering distribution and habitat use of an endangered tropical seabird, Barau's petrel Pterodroma baraui. Mar Ecol Prog Ser 423:291-302

Ponomareva LA (1966) Krill of the North Pacific, their distribution and ecology. Israel Program Sci Transl

Post E, Bhatt US, Bitz CM, Brodie JF, Fulton TL, Hebblewhite M, Kerby J, Kutz SJ, Stirling I, Walker DA (2013) Ecological consequences of sea-ice decline. Science $341: 519-524$

R Development Core Team (2008) R: a language and environment for statistical computing. Vienna, Austria: R Foundation for Statistical Computing. See: http://www.R-project.org.

Ressler PH, De Robertis A, Warren JD, Smith JN, Kotwicki S (2012) Developing an acoustic survey of euphausiids to understand trophic interactions in the Bering Sea ecosystem. Deep-Sea Res II 65-70:184-195

Schneider DC (1997) Habitat selection by marine birds in relation to water depth. Ibis 139:175-178 
591

592

593

594

595

596

597

598

599

600

601

602

603

604

605

606

607

608

609

610

611

Schneider DC, Hunt Jr. GL, Harrison NM (1986) Mass and energy transfer to seabirds in the southeastern Bering Sea. Cont Shelf Res 5:241-257

Schneider DC, Shuntov VP (1993) The trophic organization of the marine bird community in the Bering Sea. Rev Fish Sci 1:311-335

Serreze MC, Holland MM, Stroeve J (2007) Perspectives on the Arctic's shrinking sea-ice cover. Science 315:1533-1536

Serventy DL (1967) Aspects of the population ecology of the short-tailed shearwater Puffinus tenuirostris. Proc. XIV Int. Ornithol. Cong. pp 165-190

Shaffer SA, Tremblay Y, Weimerskirch H, Scott D, Thompson DR, Sagar PM, Moller H, Taylor GA, Foley DG, Block BA, Costa DP (2006) Migratory shearwaters integrate oceanic resources across the Pacific Ocean in an endless summer. Proc Nat Acad Sci USA 103:12799-12802

Shimada K, Kamoshida T, Itoh M, Nishino S, Carmack E, McLaughlin F, Zimmermann S, Proshutinsky A (2006) Pacific Ocean inflow: Influence on catastrophic reduction of sea ice cover in the Arctic Ocean. Geophys Res Lett 33:L08605.

Sigler MF, Renner M, Danielson SL, Eisner LB, Lauth RR, Kuletz KJ, Logerwell EA, Hunt Jr. GL (2011) Fluxes, fins, and feathers: Relationships among the Bering, Chukchi, and Beaufort Seas in a time of climate change. Oceanography 24:250-265

Sigler MF, Kuletz KJ, Ressler PH, Friday NA, Wilson CD, Zerbini AN (2012) Marine predators and persistent prey in the southeast Bering Sea. Deep-Sea Res II $65-70: 292-303$ 
612

613

614

615

616

617

618

619

620

621

622

623

624

625

626

627

628

629

630

631

632

633

Smith SE, Adams PB (1988) Daytime surface swarms of Thysanoessa spinifera (Euphausiaea) in the Gulf of the Farallones, California. Bull Mar Sci 42:76-84

Smith SL (1991) Growth, development and distribution of the krill Thysanoessa raschi (M. Sars) and Thysanoessa inermis (Krøyer) in the southeastern Bering Sea. Polar Res 10:461-478

Spear LB, Ainley DG (1997) Flight speed of seabirds in relation to wind speed and direction. Ibis 139:234-251

Springer AM, McRoy CP, Turco K (1989) The paradox of pelagic food webs in the northern Bering Sea - II. Zooplankton communities. Cont Shelf Res 9:359-386

Stafford KM, Moore SE, Stabeno PJ, Holliday DV, Napp JM, Mellinger DK (2010) Biophysical ocean observation in the southeastern Bering Sea. Geophys Rev Lett 37:L02606

Steele M, Ermold W, Zhang J (2008) Arctic Ocean surface warming trends over the past 100 years. Geophys Res Lett 35:L02614

Stutchbury BJM, Tarof SA, Done T, Gow E, Kramer PM, Tautin J, Fox JW, Afanasyev V (2009) Tracking long-distance songbird migration by using geolocators. Science $323: 896$

Teo SLH, Boustany A, Blackwell S, Walli A, Weng KC, Block BA (2004) Validation of geolocation estimates obased on light level and sea surface temperature from electronic tags. Mar Ecol Prog Ser 283:81-98

Toge K, Yamashita R, Kazama K, Fukuwake M, Yamamura O, Watanuki Y (2011) The relationship between pink salmon biomass and the body condition of short-tailed 
Vidal J, Smith SL (1986) Biomass, growth, and development of populations of herbivorous zooplankton in the southeastern Bering Sea during spring. Deep-Sea Res 33:523-556

Vlietstra LS, Coyle KO, Kachel NB, Hunt Jr. GL (2005) Tidal front affects the size of prey used by a top marine predator, the short-tailed shearwater (Puffinus tenuirostris). Fish Oceanogr 14:196-211

642

Wassmann P (2011) Arctic marine ecosystems in an era of rapid climate change. Prog Arctic Marine Ecosystem. Glob Change Biol 17:1235-1249

Weimerskirch H, Cherel Y (1998) Feeding ecology of short-tailed shearwaters:

Weimerskirch H, Gault A, Cherel Y (2005) Prey distribution and patchiness: factors in foraging success and efficiency of wandering albatrosses. Ecology 86:2611-2622 Arctic. J Geophys Res Oceans 119:1691-1705 
656 Woodgate RA, Weingartner T, Lindsay R (2010) The 2007 Bering Strait oceanic heat 657 flux and anomalous Arctic sea-ice retreat. Geophys Res Lett 37:L01602

658 Woodgate RA, Weingartner TJ, Lindsay R (2012) Observed increases in Bering Strait 659 oceanic fluxes from the Pacific to the Arctic from 2001 to 2011 and their impacts 660 on the Arctic Ocean water column. Geophys Res Lett 39:L24603

661 Yamamoto T, Takahashi A, Katsumata N, Sato K, Trathan PN (2010) At-sea

662 distribution and behavior of streaked shearwaters (Calonectris leucomelas) during 663 the nonbreeding period. Auk 127:871-881

664 Žydelis R, Lewison RL, Shaffer SA, Moore JE, Boustany AM, Roberts JJ, Sims M, 665 Dunn DC, Best BD, Tremblay Y, Kappes MA, Halpin PN, Costa DP, Crowder LB 666 (2011) Dynamic habitat models using telemetry data to project fisheries bycatch. $667 \quad$ Proc Royal Soc B 278:3191-3200 


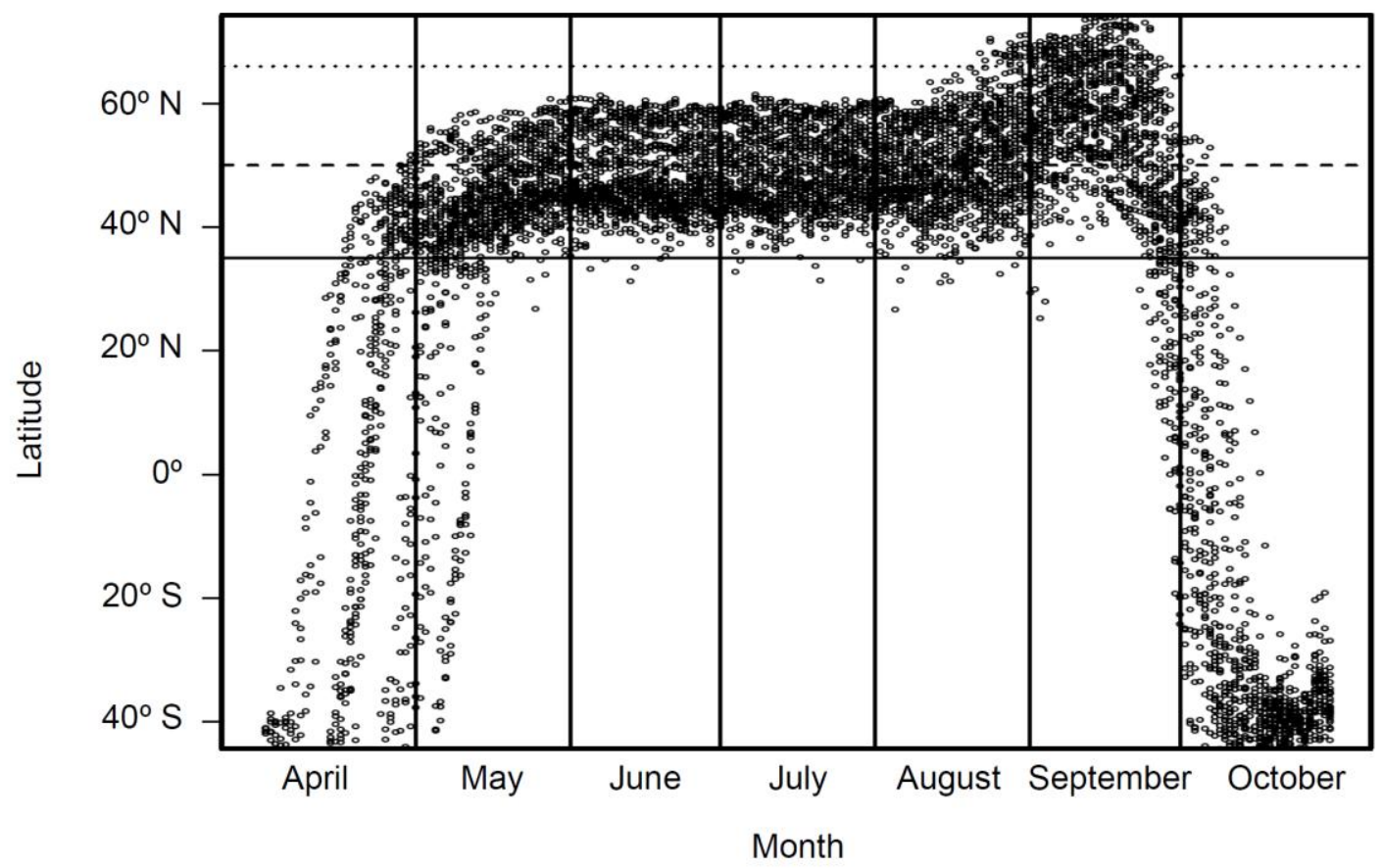

Fig. 1 Latitudinal movements of short-tailed shearwaters between the breeding colony $\left(40^{\circ} 15^{\prime} \mathrm{S}\right)$ and the North Pacific during the non-breeding period (April to October). 


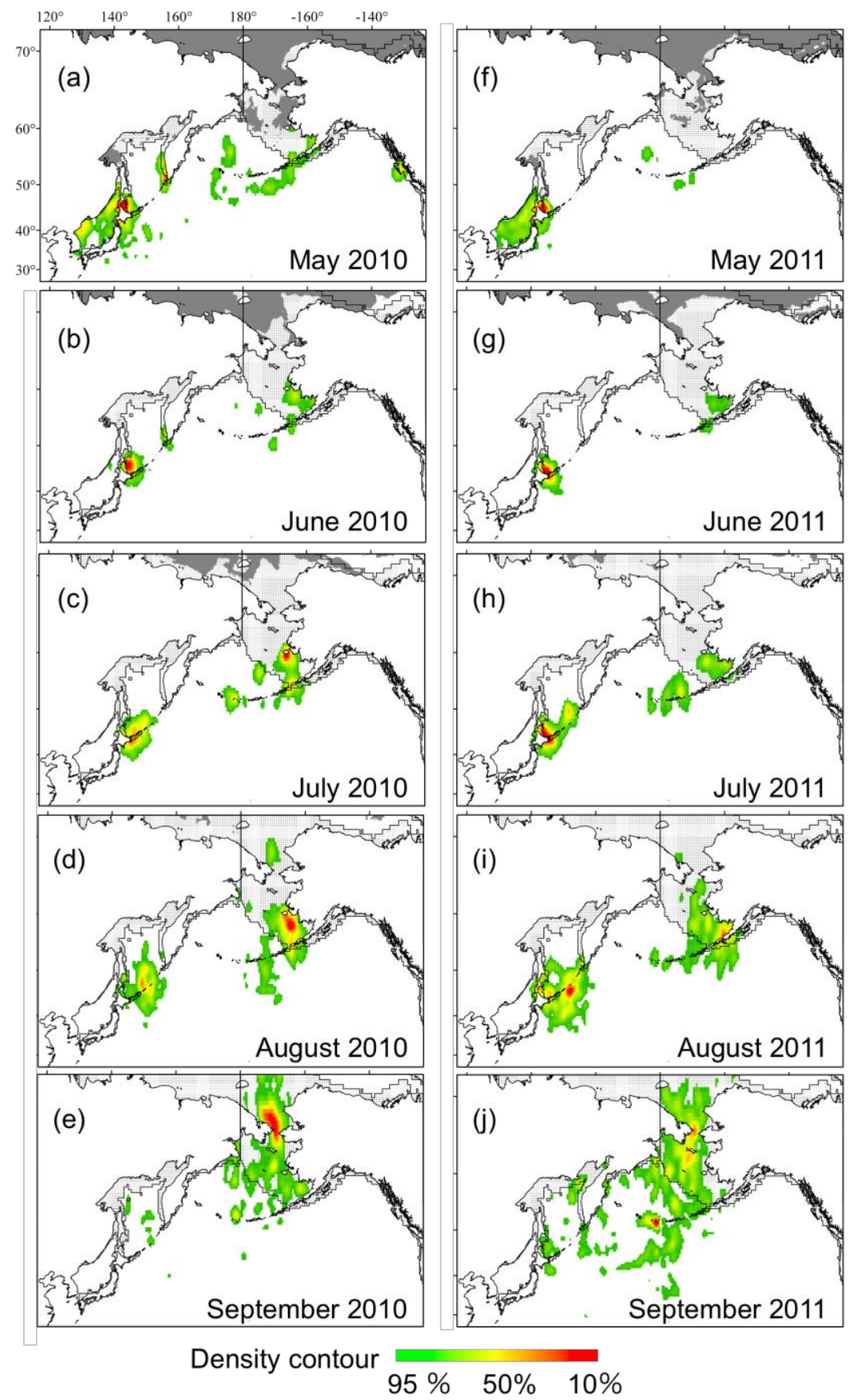

Fig. 2 Seasonal changes in at-sea distribution of tracked short-tailed shearwaters during the non-breeding period in (a) May 2010, (b) June 2010, (c) July 2010, (d) August 2010, (e) September 2010, (f) May 2011, (g) June 2011, (h) July 2011, (i) August 2011, and (j) September 2011. Density distribution of the tracked shearwaters are shown in relation to the extent of water of $<200 \mathrm{~m}$ depth contour (dotted area bordered by thin lines) and $>10 \%$ sea ice concentration (AMSER-E). 

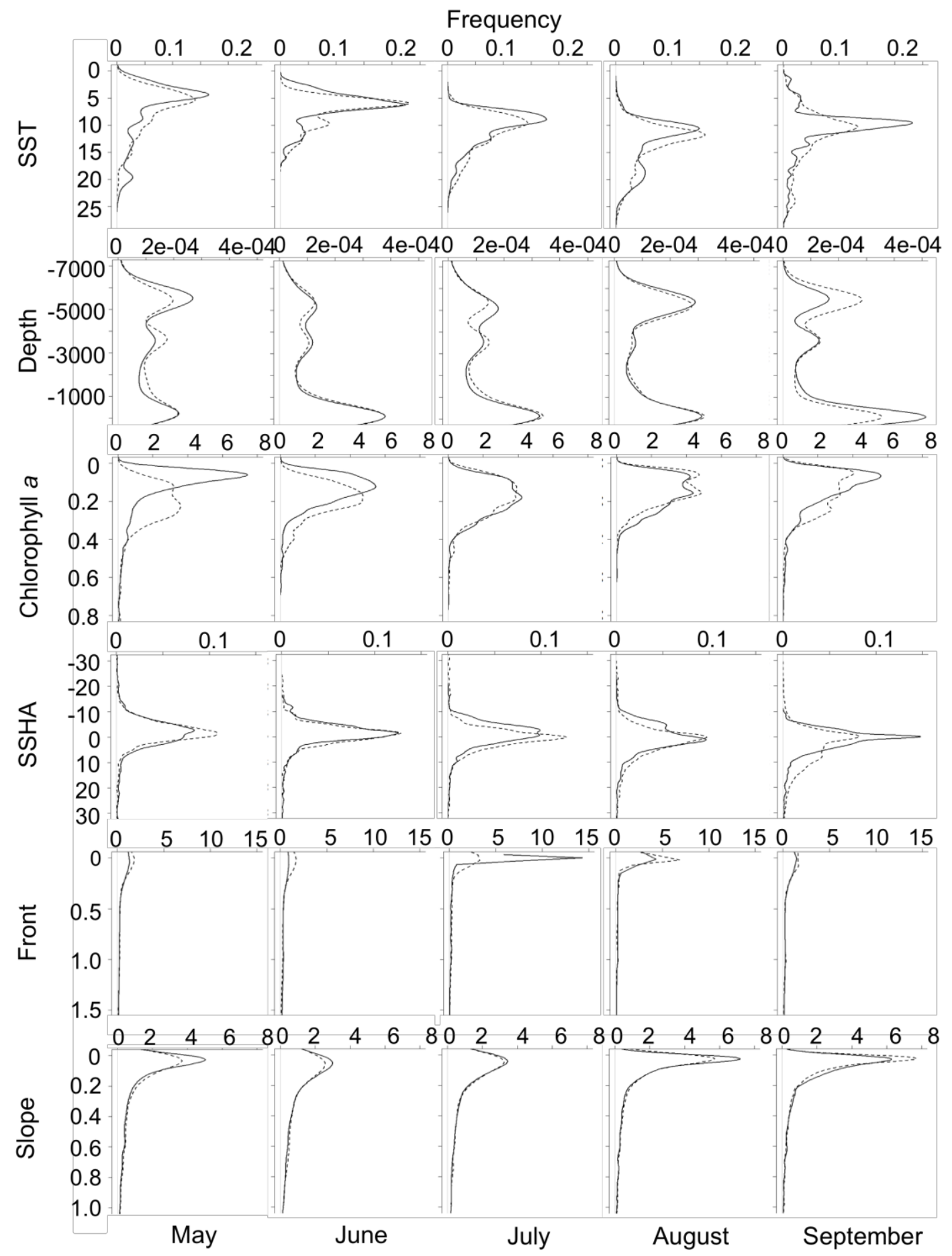

Fig. 3 Smoothed histograms of six environmental variables within 95\% kernel density distribution of the tracked short-tailed shearwaters for each month (May-September 2010 (black lines) and 2011 (dashed lines)): sea surface temperature (SST), bathymetry (depth), chlorophyll a concentration (productivity), sea surface height anomalies (SSHA), SST gradient (front), and bathymetry gradient (slope). 

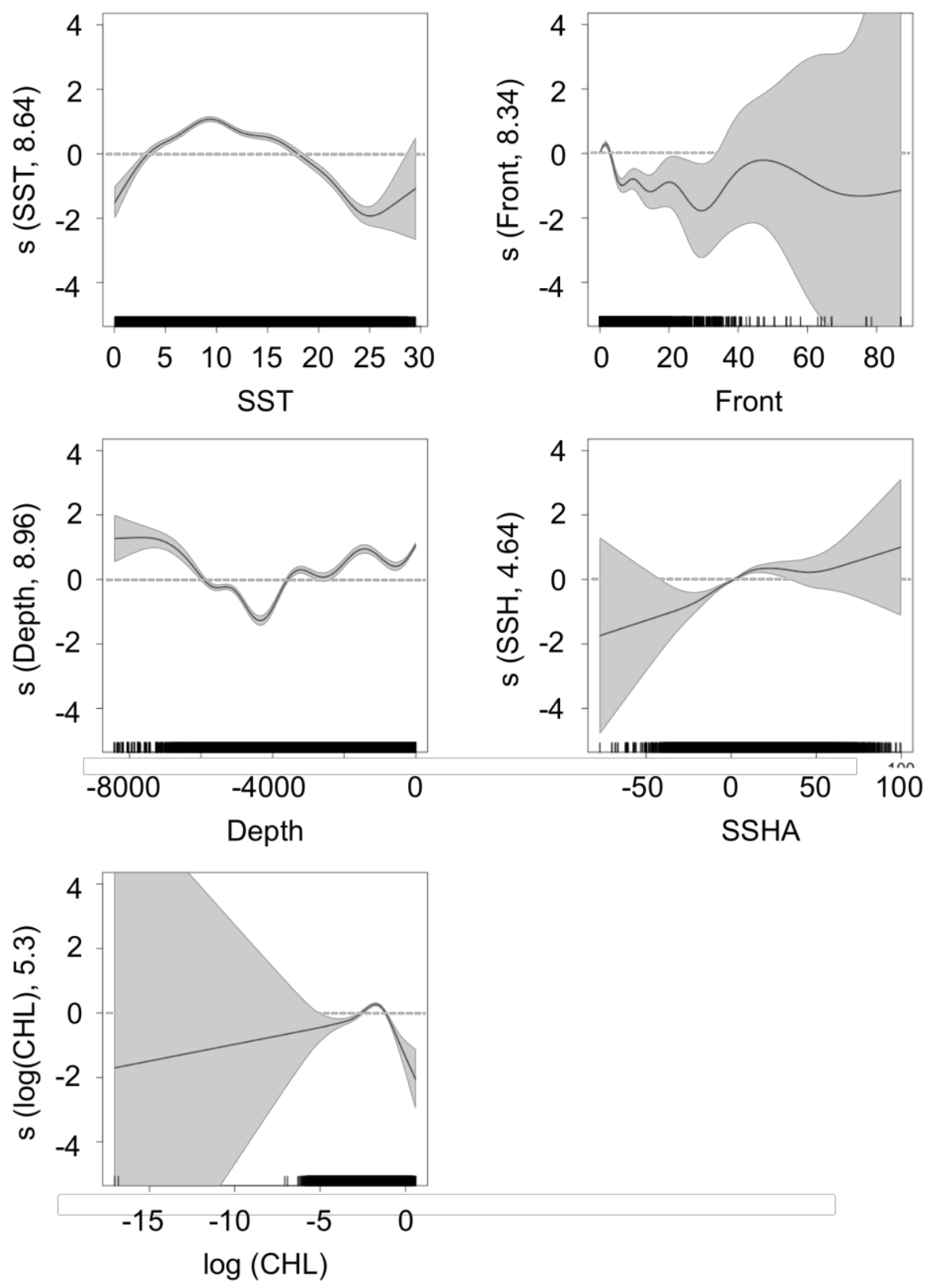

Fig. 4 Response curves of the five influential variables in the oceanographic habitat model (GAM) of short-tailed shearwaters tracked during the non-breeding period. 

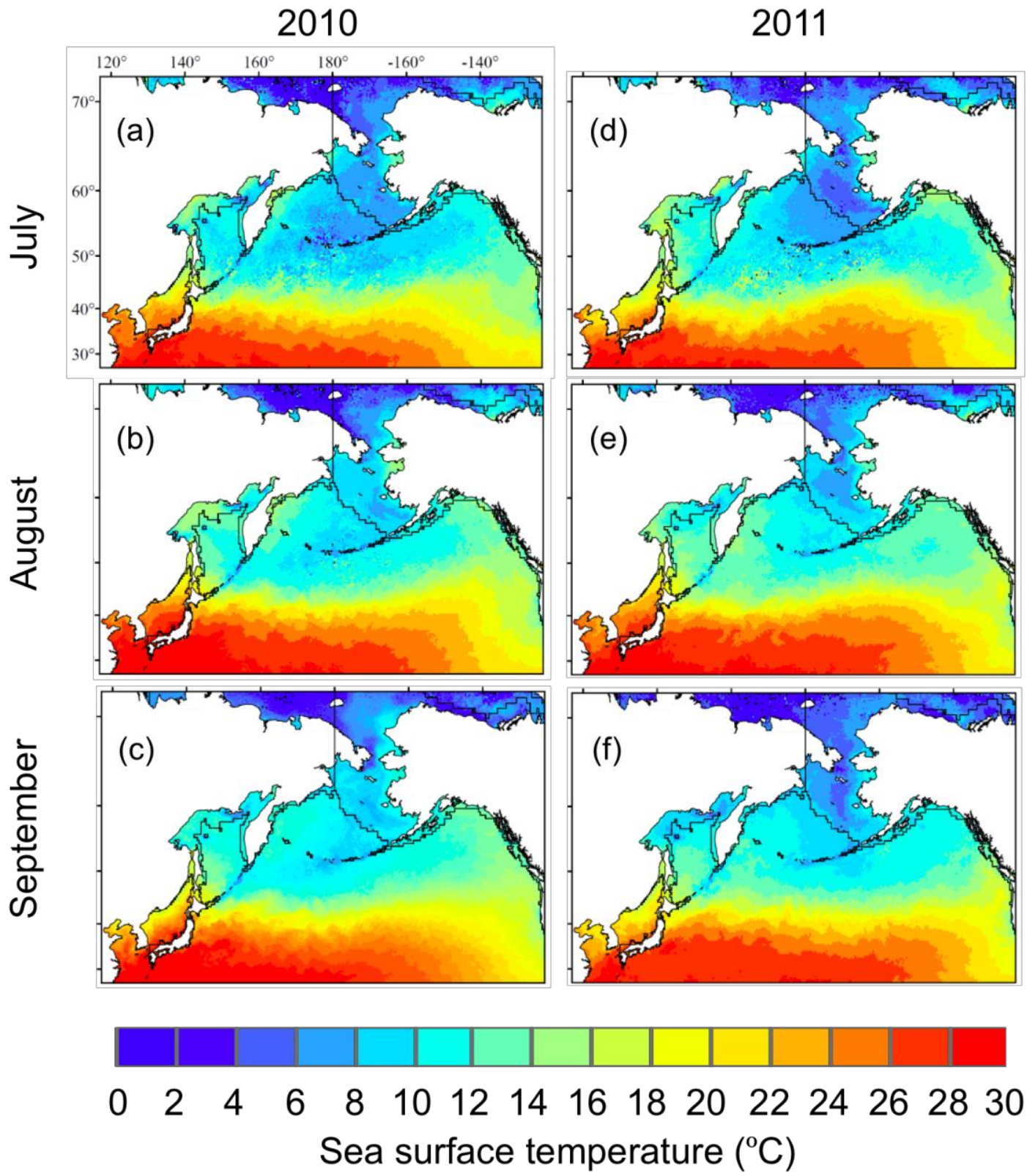

Fig. 5 Seasonal and annual differences in sea surface temperatures (SST: AVHRR) in the non-breeding range of short-tailed shearwaters: (a) July 2010, (b) August 2010, (c) September 2010, (d) July 2011, (e) August 2011, and (f) September 2011. The black color indicates areas where no data was available, or SSTs cooler than $0{ }^{\circ} \mathrm{C}$ or warmer than $30^{\circ} \mathrm{C}$. 


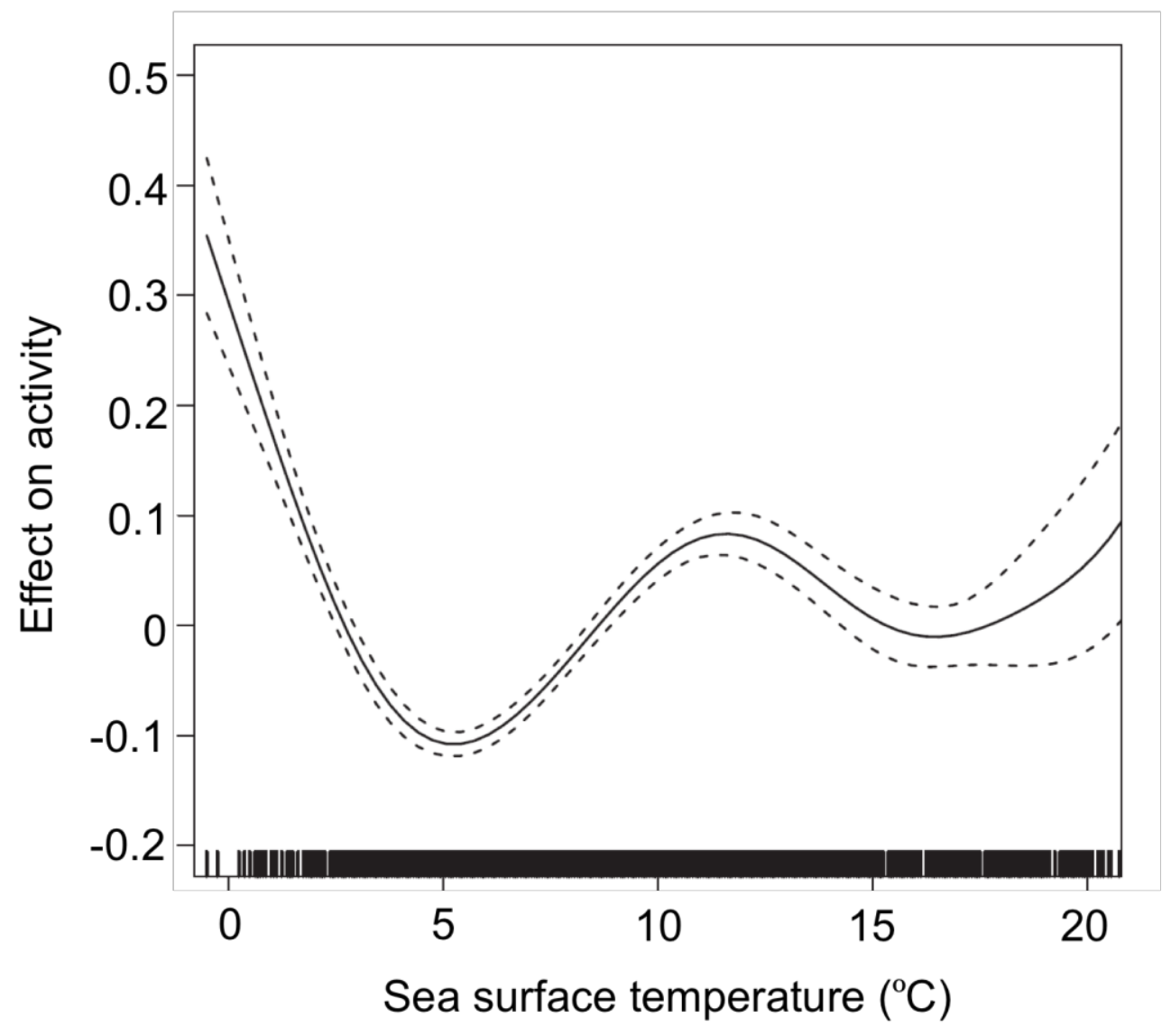

Fig. 6 Fitted relationship between at-sea activity (time spent in continuous flight) and water temperature of short-tailed shearwaters tracked during the non-breeding period. 
Table 1 Estimates of parameter Chi-square values and significance of the most plausible habitat models of tracked short-tailed shearwaters using the reduced (either data in 2010 or 2011) and full (data both in 2010 and 2011) datasets. Dashes indicate variables that were eliminated during the process of model selection using AIC.

\begin{tabular}{|c|c|c|c|c|c|c|}
\hline \multirow[b]{2}{*}{ Variable } & \multicolumn{2}{|c|}{2010 dataset } & \multicolumn{2}{|c|}{2011 dataset } & \multicolumn{2}{|c|}{$2010 \& 2011$ dataset } \\
\hline & $x^{2}$ & $P$ & $x^{2}$ & $P$ & $x^{2}$ & $P$ \\
\hline Depth & 388.5 & $<0.01$ & 394.1 & $<0.01$ & 746.7 & $<0.01$ \\
\hline Slope & - & - & - & - & - & - \\
\hline Productivity & 142.6 & $<0.01$ & 50.2 & $<0.01$ & 172.0 & $<0.01$ \\
\hline SST & 383.4 & $<0.01$ & 632.9 & $<0.01$ & 931.8 & $<0.01$ \\
\hline Front & 122.7 & $<0.01$ & 84.8 & $<0.01$ & 186.2 & $<0.01$ \\
\hline $\mathrm{SSH}$ & 30.2 & $<0.01$ & 160.7 & $<0.01$ & 88.2 & $<0.01$ \\
\hline $\mathrm{AIC}$ & & & & & & \\
\hline
\end{tabular}


Electronic Supplementary Material (Tables, Figures, Video, Movie, Audio, etc.)
Click here to download Electronic Supplementary Material (Tables, Figures, Video, Movie, Audio, etc.): TY_ESM_FINAL.pdf

Electronic Supplementary Material (Tables, Figures, Video, Movie, Audio, etc.)
Click here to download Electronic Supplementary Material (Tables, Figures, Video, Movie, Audio, etc.): TY_ESM_FINAL.pdf

Electronic Supplementary Material (Tables, Figures, Video, Movie, Audio, etc.)
Click here to download Electronic Supplementary Material (Tables, Figures, Video, Movie, Audio, etc.): TY_ESM_FINAL.pdf

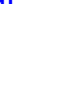

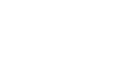

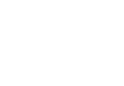

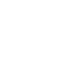
.

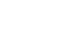
. . . . . . . . . . . . . . . . . . . . . .

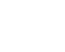
. . . . . .

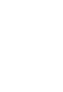

